\title{
The State of Indian Agronomy: Introduction of Modern Methods
}

\author{
Pranab Roy* \\ Haldia Institute of Technology, India \\ *Corresponding author: Pranab Roy, Haldia Institute of Technology, India
}

Submission: 眥 January 12, 2018; Published: 每 April 13, 2018

\section{Introduction}

Since our independence, India was a net importer of food grains to meet our domestic needs. We used to import wheat from USA under PL480 scheme and also oilseeds, pulses etc. from Australia. However, after the green revolution ushered in mid-60's, the country became self sufficient in food production. The annual production of food grains increased from 50 Million Metric Tonnes (mmt) to $200 \mathrm{mmt}$ in a span of 20 years, a remarkable achievement. This was possible due to the introduction of high yielding varieties of seeds, dwarf varieties of rice and wheat and usage of chemical fertilizers, insecticides, pesticides and fungicides.

The application of NPK needed by the plants through urea, Di-ammonium phosphate, superphosphate of lime and potash or $\mathrm{KCl}$ in abundance led to vigorous growth, both vegetative and reproductive in the crop plants. However, the situation began to change from early 90's when the increase in yields of the plants was tapering off. After obtaining $220 \mathrm{mmt}$ annual productions in the beginning of the new millennium, the yield curve started to show plateau, as per the Law of Diminishing Returns. So scientists investigated the reasons and came up with the following:

a) Too much usage of chemical fertilizers led to the extinction of the natural microbes in the soil, which helped the growth of the plants.

b) Agricultural soil lost the porosity which led to lower retention of water, ultimately producing drought.

c) Slow acidification of the soil due to overuse of chemicals in the form of fertilizers, insecticides, pesticides and fungicides.

To overcome this situation, an improved approach to agriculture in the form of Integrated Farm Management has been introduced. This involves rational use of all the chemical inputs and biofertilizers, biopesticides and bioinsecticides. The organic carbon in agricultural soil which was almost depleted during the initial phase of the green revolution is being supplemented by organic manure, like vermi-compost or compost made from village/ municipal solid waste. This should restore the population of the natural microflora in the soil, beneficial to plant's growth.
The second approach is to supply microbial biofertilizers, helpful to the crop plants which act as inocula for the growth of the Nitrogen fixing organisms, phosphate solubilizing microbes and Plant Growth Promoting Rhizobacteria. The free living Nitrogen Fixers like Azotobacter, Azospirillum can be used to inoculate crops like rice, wheat etc. but symbiotic Nitrogen fixers like Rhizobium sp. occur in root nodules of leguminous plants only. Novel species of symbiotic Nitrogen fixers like Enterobacter and Pantoea genus have been isolated which increases the host range of the leguminous plants. The Plant Growth Promoting Rhizobacteria (PGPR) activities of the different microbes include:

1. Nitrogen Fixation

2. Phosphate Solubilization

3. Plant hormone production

4. Siderophore production

5. ACC Deaminase production

The plant hormone production by the microbes in the nodules help the growth of the host, e.g. Indole Acetic Acid, Gibberelins and cytokinins are known to be produced by different nodule associated bacteria.

Siderophores are organic compounds synthesized by these microbes which are secreted in the surrounding soil which can chelate iron which is available as insoluble Fe (III) salts. Catechols or Hydroxamates are commonly synthesized as the siderophores. ACC Deaminase is the enzyme which breaks down ACC (1-amino, 1-carboxyl cyclopropane) which is the precursor of the plant hormone Ethylene. This is produced during senescence phase of a plant and is inhibitory to the growth of the plant. Hence the microbial enzyme ACC Deaminase helps in the vigorous growth of the host plant. Use of the modern methods using microbial biofertilizers and organic manure and reduction of the chemical fertilizers are the future directions imperative for agronomic growth of India. 

(c) (i) Creative Commons Attribution 4.0

For possible submissions Click Here

Submit Article
MCDA Modem concepts a dovelopmen
nAggonomy ,

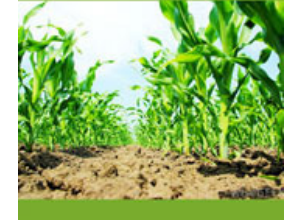

Modern Concepts \& Developments in Agronomy

\section{Benefits of Publishing with us}

- High-level peer review and editorial services

- Freely accessible online immediately upon publication

- Authors retain the copyright to their work

- Licensing it under a Creative Commons license

- Visibility through different online platforms 